\title{
Inter-rater Reliability of the Qol-measure QUALIDEM
}

\author{
Martin Dichter \\ From The European Academy of Nursing Science EANS Summer Conference \\ Barcelona, Spain. 8-9 July 2015
}

\section{Background}

Improving access to health and nursing care aims to maintain and promote the quality of life (Qol) of care recipients. Especially in dementia research, Qol is a major outcome. QUALIDEM is an often-used dementiaspecific Qol measure. It consists of two consecutive versions, one for mild to severe and one for very severe dementia. Previous results showed an insufficient interrater reliability (IRR).

\section{Aims}

Development of a user guide for the measurement and the evaluation of the IRR of QUALIDEM.

\section{Methods}

The study was conducted in two steps: (1) A QUALIDEM user guide was developed, based on 11 cognitive interviews with 16 nurses experienced in dementia care. (2) The item "Distribution" and the IRR of the QUALIDEM were evaluated in a field test including $\mathrm{n}=55$ (mild to severe) and $n=36$ (very severe dementia) residents from nine nursing homes. The people with dementia were assessed four times by blinded proxy-raters. Proxy-raters were nurses and nursing assistants $(n=40)$ who knew the people with dementia well. The proxy-ratings were led by a trained researcher and followed the user guide. The intra-class correlation coefficients (ICC) were calculated for each QUALIDEM subscale separately.

\section{Results}

The user guide includes definitions and examples for each item. The distribution of the responses of all 40 QUALIDEM items $(\mathrm{n}=40)$ was examined, indicating floor

\footnotetext{
Correspondence: Martin.Dichter@dzne.de

German Centre for Neurodegenerative Diseases (DZNE), Witten, Germany,

and Department of Health, School of Nursing Science, Herdecke University,
} Witten, Germany

Submit your next manuscript to BioMed Central and take full advantage of:

- Convenient online submission

- Thorough peer review

- No space constraints or color figure charges

- Immediate publication on acceptance

- Inclusion in PubMed, CAS, Scopus and Google Scholar

- Research which is freely available for redistribution 